\title{
Determinants of Food Security among Rural Livestock Farmers in Southwestern Nigeria
}

\author{
Owolade, E. O. ${ }^{1}$, Oyesola, O. B. ${ }^{2}$ Yekinni O. T. and Popoola M. A. ${ }^{3}$ \\ ${ }^{1}$ Department of Agricultural Extension and Management, Federal college of Animal and \\ Production Technology, Ibadan \\ ${ }^{2}$ Department of Agricultural Extension and Rural Development, University of Ibadan \\ ${ }^{3}$ Department of Animal Health and Production, Federal College of Animal and Production \\ Technology, Ibadan \\ E-mail: ofowolade@yahoo.com, Tel: 08038014153
}

\begin{abstract}
This study examined the extent to which livestock production has contributed to food security of the rural households in Southwestern Nigeria. Multistage sampling procedure was used to select respondents for the study. Fifty percent of the states in Southwestern Nigeria and 30\% of rural households in the selected local government areas were randomly selected resulting in a sample size of 306 respondents. Household food insecurity access scale (HFIAS), food insecurity scale was used to assess the food insecurity of the respondents. Data were analyzed using descriptive statistics while binomial regression was used to determine the determinants of food security at $p=0.05$. Most respondents (76.1\%) were males and married (83.7\%), while about half $(46.0 \%)$ of them completed secondary education. Mean age, household size and monthly income from livestock enterprises were $48.8 \pm 12.8$ years, $6.6 \pm 3.2$ and $\mathrm{N45,068 \pm}$ 97,077 , respectively. A large proportion (71.9\%) practiced extensive system of livestock production. Sources of information $(\beta=5.304)$, income $(\beta=7.453)$ and constraints to livestock enterprises $(\beta=2.807)$ increased the odds of their food security. Policies that encouraged that promote diversification of income sources should be promoted to increase entrepreneurs' income in order to improve food security situation of rural households.
\end{abstract}

Keywords: Rural, Livestock Production, Food Security, Southwestern

\section{Introduction}

Livestock production in Nigeria is achieved mostly through 'nomadic pastoral' and rural households' production of cattle, sheep, goat, pigs, poultry (ducks, guinea fowl and chicken) and rabbit at subsistence level. Livestock production accounts for about only $2 \%$ of the GDP. It is an asset as well as source of income for many Nigerians, creating employment opportunities, source of revenue to the government (tax and export), source of food and meat that partly satisfy the animal protein requirement, provides animal manure for crop production and provides power and transport options (Onigbinde, 2009). The importance of livestock cannot be over-emphasised, considering the role they play in the society. Livestock make use of left-over products, such as meat, milk, eggs, fibre etc. In addition to providing food, they provide income and other useful product to the people. They contribute substantially to the livelihood of many rural households (Duru, 2006)

Food insecurity is a worldwide problem even in developed countries with well developed agriculture. The root of food insecurity in Africa is said to be extreme poverty and poor agricultural productivity (Mwaniki, 2005). This becomes a major problem since majority of the households are poor and do not have the purchasing power to procure food the food they need particularly with the soaring inflation rate (Olorunfemi and Aderinola, 2005)

In order to utilise and build on the potentials of livestock's contribution to the livelihoods of communities in developing countries, it requires improved understanding of livestock's multiple and complex roles. This will enable meaningful intervention that will 
lead to meaningful contributions to the livelihood of the livestock entrepreneurs. The role of livestock production in achieving food security in Nigeria cannot be overemphasised. It advocates support for smallholders both in responding to opportunities in livestock production and in finding other opportunities within a broad rural development strategy (FAO, 2009).

Livestock is central to the integrity, identity and autonomy of rural dwellers. Household food security and family nutrition influence successful and healthy family living. Any move to improve the livestock and household food security strategies of rural dwellers in Southwest Nigeria must be seen as an attempt to improve and develop the rural economy generally. When the mentioned desirable developments are achieved in people, then there is an improvement. It is therefore important to ascertain the indicators to the achievements in empirical terms at various locations because the issue can be viewed as cultural and location specific. Thus, the objective of this study was to assess the contributions of livestock production to rural household food security in Southwest Nigeria.

The specific objectives of the study were to;

1. ascertain the socioeconomic characteristics of respondents;

2. identify the livestock enterprise characteristics of respondents; and

3. determine the determinant of food security among respondents

\section{Methodology}

The study was carried out in the Southwest region of Nigeria, which lies between latitude $5^{\circ} 8^{\prime}$ and $9^{\circ} 10^{\prime}$ and has an area of $114.27 \mathrm{~km}$ representing $12 \%$ of the country's total land mass. The target population of the study consisted of all rural dwellers that reared livestock in the Southwest of Nigeria. A multi-stage sampling procedure was adopted to select the respondents of the study. The first stage involved the selection of $50 \%$ of the states in the region i.e. Ekiti, Osun and Oyo. The second stage involved the stratification of local government areas (LGAs) in the selected states on rural-urban basis and random sampling of $30 \%$ of rural LGAs. The third stage involved purposive selection of livestock farmers groups in the selected LGAs. The fourth stage involved a random selection of $30 \%$ of group members involved in livestock production, giving a sample size of 306 respondents. Household Food Insecurity Access Scale (HFIAS) of the USAID was used to assess the food insecurity status of the respondents. Data collected were analysed using descriptive statistics such as frequency and percentages while binomial regression model was used to determine the determinants of food security among the respondents at $p=0.05$.

\section{Results and Discussion}

\section{Socioeconomic characteristics of respondents}

Results in Table 1 show that more males (76.1\%) were involved in livestock production than females (23.9\%). This finding is similar to report of Ajala, (2005), that although the role of women in livelihood activities is very important, majority of the respondents were male. In terms of age distribution of the respondents, majority of them were in their economically active ages, (mean $=48$ years). This implied that the respondents will be active based on their ages. This finding agrees with Salimonu, (2005) who also reported a mean age of 48 years for farmers in Osun state.

Almost half of the respondents had secondary education. This implies that the respondents are fairly educated in the study area and may not find it difficult to access information from a wide range of sources. Asanwana, (2001) opined that educated 
farmers can easily understand and adopt new innovations to improve their practices. As regards household size, the average household size was 6.6. This result is similar to that of Odebode and Munsong (2001) and Bammeke (2003) who reported household size of between 6 and 10 people as the modal family size among rural households.

Almost half $(47.7 \%)$ of the respondents made less than $\$ 10,000$ per month, while 12.1 percent of them made $\$ 55,000$ and above per month. The incomes from the entrepreneurs are very low and an indication that majority of the respondents are small scale farmers. This is expected to have effects on their households' food security.

Table 1: Distribution of respondents based on selected socio-economic characteristic

\begin{tabular}{llll}
\hline Variables & Frequency & Percentage & Mean \\
\hline Age: & 10 & & 48.4 \\
$\leq 25$ & 38 & 12.4 & \\
$26-35$ & 71 & 23.2 & \\
$36-45$ & 87 & 28.4 & \\
$46-55$ & 60 & 19.6 & \\
$56-65$ & 40 & 13.1 & \\
65 and above & & & \\
Educational Attainment & 54 & 16.3 & \\
No Formal Education & 80 & 26.1 & \\
Primary & 141 & 46.1 & \\
Secondary & 31 & 10.1 & \\
Tertiary & & & \\
Household size & 137 & 44.8 & \\
$1-5$ & 129 & 42.2 & \\
6-10 & 37 & 12.1 & \\
$11-15$ & 3 & 1.0 & (SD=182, \\
$16-20$ & & & $986)$ \\
Household income (In Naira) & 146 & 47.7 & \\
$<10,000$ & 58 & 19.0 & \\
$10,000-24,000$ & 29 & 9.5 & \\
$25,000-39,000$ & 36 & 11.8 & \\
$40,000-54,000$ & 37 & 12.1 & \\
55,000 and above & & & \\
\hline
\end{tabular}

Figure1 presents the various primary occupations of the respondents. The study showed that majority $(80.1 \%)$ of the respondents were farmers, while other occupations like trading $(10.1 \%)$, civil service $(9.2 \%)$ and artisans $(0.7 \%)$ were practiced by the respondents. This implied that the main source of livelihood for majority of the respondents is farming; it also implied that the rural dwellers are diversified into other income generating activities as means of increasing their income and improving on their access to food. This finding corroborates the finding of Sodiya (2005) who reported that majority of livestock farmers are also growing crops as their livelihood. 


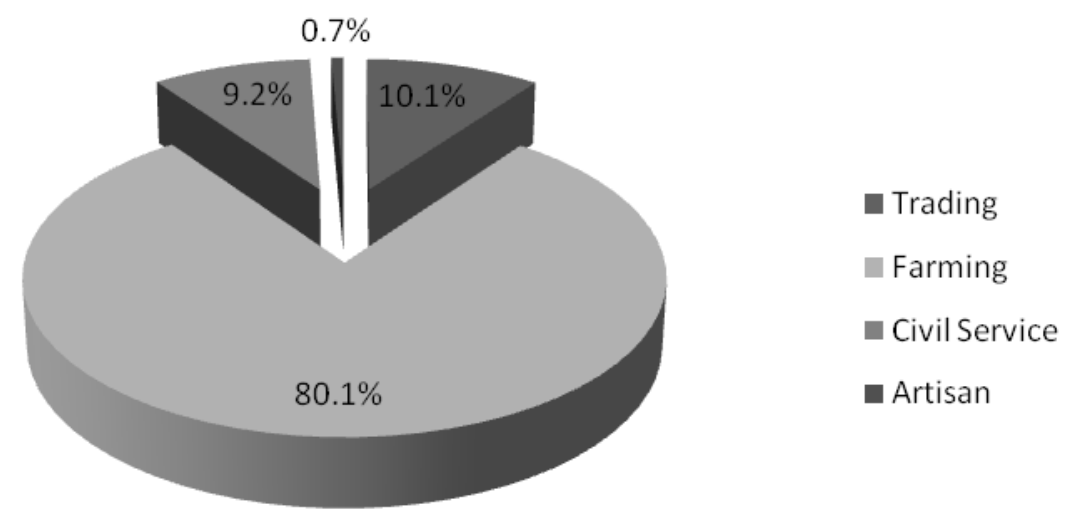

Figure 1: Distribution of respondents based on their occupation

\section{Enterprise characteristics}

The number of livestock owned by respondents has a direct relationship with their food security status. Table 2 shows that majority $(67.6 \%$ and $61.8 \%)$ of the respondents owned between 1 and 10 of sheep and goats respectively. Further, 19.1\% and $29.1 \%$ of the respondents kept between 11 and 20 sheep and goats respectively. In terms of poultry production, majority of the respondents did not keep turkey (81.1\%), duck (79.7\%) and guinea fowl (85.6\%). However, 68.0\% and 19.3\% kept between 1 and 20 and 21 and 40 chickens respectively. This implies that most of the respondents are small scale producers of poultry. The general implication of these findings is that respondents in the study area were mainly small scale livestock farmers. This showed that majority of these respondents were engaged livestock production as complementary to farming, which is the primary occupation to most of them. This finding is in agreement with that of Pollot and Wilson (2009), who reported that livestock production are favoured by small scale farmers because low capital are required.

Results from the table also showed that most $(67.3 \%)$ of the respondents had more than 30 years of experience in livestock enterprises, $71.9 \%$ of them are into extensive production method, with $39.5 \%$ using medication for the animals while only $18.9 \%$ of them feed animals with concentrate feeds. These findings revealed that most of the livestock entrepreneurs are not into intensive production activities and are mostly at small scale level. 
Journal of Agricultural Extension

Vol.17 (2) December, 2013

ISSN 1119-944X

Table 2: Distribution of respondents by livestock enterprise characteristics

\begin{tabular}{|c|c|c|}
\hline Number of animals & Percentage $(n=306)$ & Mean \\
\hline \multicolumn{3}{|l|}{$\begin{array}{l}\text { Number of animals } \\
\text { Sheep: }\end{array}$} \\
\hline $1-10$ & 67.6 & \\
\hline $11-20$ & 19.9 & 9.7 \\
\hline $21-30$ & 2.9 & \\
\hline $31-40$ & 0.7 & \\
\hline $41-50$ & 1.0 & \\
\hline None & 5.9 & \\
\hline \multicolumn{3}{|l|}{ Goat } \\
\hline $1-10$ & 61.8 & \\
\hline $11-20$ & 29.1 & 9.6 \\
\hline $21-30$ & 4.9 & \\
\hline $31-40$ & 0.3 & \\
\hline $41-50$ & 1.0 & \\
\hline Above 50 & 0.7 & \\
\hline None & 2.3 & \\
\hline \multicolumn{3}{|l|}{ Turkey } \\
\hline None & 81.1 & \\
\hline $1-10$ & 14.1 & 8.1 \\
\hline $11-20$ & 3.6 & \\
\hline $21-30$ & 0.7 & \\
\hline Above 30 & 19.0 & \\
\hline \multicolumn{3}{|l|}{ Duck: } \\
\hline $1-10$ & 15.7 & \\
\hline $11-20$ & 4.2 & 1.8 \\
\hline $21-30$ & 0.3 & \\
\hline None & 79.7 & \\
\hline \multicolumn{3}{|l|}{ Guinea fowl } \\
\hline None & 85.6 & \\
\hline $1-10$ & 12.4 & \\
\hline $11-20$ & 1.3 & \\
\hline \multirow{2}{*}{\multicolumn{3}{|c|}{ Local Chicken }} \\
\hline & & \\
\hline $1-20$ & 68.0 & \\
\hline $21-40$ & 19.3 & 16.5 \\
\hline $41-60$ & 7.5 & \\
\hline $61-80$ & 0.1 & \\
\hline $81-100$ & 0.1 & \\
\hline None & 3.9 & \\
\hline \multicolumn{3}{|l|}{ Years of experience } \\
\hline $1-10$ & 3.6 & \\
\hline $11-20$ & 8.8 & 24.6 \\
\hline $21-30$ & 20.3 & \\
\hline Above 30 & 67.3 & \\
\hline \multicolumn{3}{|c|}{ Method of production } \\
\hline Extensive & 71.9 & \\
\hline Semi-intensive & 28.1 & \\
\hline \multicolumn{3}{|l|}{ Medication } \\
\hline No medication & 60.5 & \\
\hline Self Medication & 39.5 & \\
\hline \multicolumn{3}{|l|}{ Mode of feeding } \\
\hline Free range only & 44.4 & \\
\hline Local feed material & 49.0 & \\
\hline Concentrates & 18.9 & \\
\hline
\end{tabular}




\section{Determinant of food security of rural livestock producers in the study area}

A binomial regression analysis was carried out to ascertain the predictor variables for the food security status of households involved in livestock production in the rural areas of Southwestern Nigeria. The results in Table 3 indicated that constraints $(B=$ $0.177)$, source of information $(B=0.333)$ and income $(B=0.461)$ were the significant predictors of food security of livestock entrepreneurs in the study area. The findings of this study established that income of the livestock farmers, in expectation of what it can contribute to their food security, was significant to the livestock entrepreneurs' food security. It also showed that those who had substantial constraints to their enterprises could not attain food security, while those who had fewer constraints were food secured. This, by implication, supported the importance of livestock enterprises to food security in the study area. The study also established that those who had substantial access to information on livestock enterprises are more food secured than those who do not. This stressed the importance of knowledge support activities for the livestock enterprises in the study area. Other listed variables that were found not to be significant were sex, age, formal education, other education, household size and years of the experience.

Table 3: Binomial regression analysis for the determinants of household food security status among rural livestock farmers in the study area

\begin{tabular}{llll}
\hline Variables & Coefficient $(\boldsymbol{\beta})$ & t-value & p-value \\
\hline Constant & & 2.534 & 0.012 \\
Sex & 0.034 & 0.493 & 0.622 \\
Age & 0.051 & 0.729 & 0.467 \\
Formal education & 0.032 & 0.510 & 0.611 \\
Educational attainment & 0.068 & 1.040 & 0.300 \\
Sources of information & 0.333 & 5.304 & $0.000^{*}$ \\
Income from livestock & 0.461 & 7.453 & $0.000^{*}$ \\
Sex of household head & 0.092 & 1.446 & 0.151 \\
Years of experience & 0.071 & 1.049 & 0.296 \\
Constraints & 0.177 & 2.807 & $0.006^{*}$ \\
\hline
\end{tabular}

${ }^{*} p<0.05$

\section{Relationship between income realised by respondents from livestock enterprises and their food security status}

The relationship between income and food security $(r=0.5)$ was significant $(p<0.05)$ the finding implies that income realized from livestock enterprises significantly contribute to the household food security status of the respondents. This finding is in line with that of Asanwana (2001) who found that increases in income of the respondents, ensured their food security. The finding is in line with the a-priori expectation of the study that there should be positive significant relationship between income and food security.

\section{Conclusion and Recommendation}

The study noted that livestock entrepreneurs in Southwest Nigeria are mostly middle aged people, of fairly large household sizes and low level income because of their small scales of operation. The foregoing laid a very serious implication for food security of the entrepreneurs in the study area. The study established that most of the respondents diversified into other enterprises in order to augment their income. Income from the enterprises, access to information and constraints to livestock enterprises significantly affected food security of the livestock entrepreneurs. 
Based on the findings of the study, the following recommendations were made.

- Rural development activities should always be made to encourage diversification into other income - generating activities so as to improve their income and hence food security

- Efforts at making livestock enterprise information available to rural people should be intensified at all levels in order to improve their enterprise performance as well as food security outcome

- Development organisations should endeavour to ascertain relevant constraints to livestock entrepreneurs and make efforts to address them in order to improve their activities and enhance the food security outcome.

\section{References}

Ajala, C. G. (2005): Livelihood and household food security strategies of rural dwellers in selected local government areas of Osun state. Ph. D Thesis. Department of Agricultural Extension and Rural Development, University of Ibadan, Nigeria

Asanwana, V. A. (2001): Coping strategies for Enhanced Rural Household Food Security among Female Farmers in Akwa Ibom state, Nigeria Ph.D thesis, Department of Agricultural Extension and Rural Development, University of Ibadan, Ibadan.

Bammeke, T .O. A. (2003). Accessibility and utilization of agricultural information in the economic empowerment of women farmers in South-western Nigeria. Ph.D. Thesis, Department of agricultural Extension and Rural Development, University of Ibadan, Nigeria.

Duru, C. (2006): Livestock activities among peri- urban households of Ibadan metropolis. Unpublished B.SC dissertation Department Agric Extension and Rural Development, University of Ibadan, Nigeria

Food and Agricultural Organisation (2009): Livestock in the balance. State of Food and Agriculture 2009, FAO Rome

Odebode, S. O. and C. H. Mungong (2001): Poverty alleviation strategies of rural households in Mezan Division, North West Province, Cameroon, Moor Journal of Agricultural Research 2.2: 179 - 185

Olayemi, J. K. (2005): Issues in the Nigerian Food Security Working paper, Developing Policy Centre, Ibadan, Nigeria

Olorunfemi, S., Aderinola, E. A. (2009): Nigeria food security up date, Department of Food Security in South Western Nigeria

Onigbinde, T. O. (2009): Agricultural, renewable natural resources. Animal Husbandry and Health publishers, Forest research Institute of Nigeria (FRIN).

Pollot, G. and R. T. Wilson (2009): Sheep and Goats for Diverse Products and Profits (Food and Agricultural Organisation, Rome. 
Rychentnk, L., K. Webb, L. Story and Katz, T. (2003): Food security options Paper: A planning Framework and Mean of options Development, Publisher University of Ibadan.

Salimonu, K. K. (2005): Attitude to risk in resource allocation among food crop farmers in Osun state, Nigeria PhD thesis, Department of Agricultural Economics, University of Ibadan, Oyo state, Nigeria.

Sodiya, A. (2005): Assessment of Agricultural Extension Service, Availability and Need in Agro-pastoral production systems of Ogun State, Nigeria. Ph.D Thesis, Department of Agricultural Extension and Rural Development, University of Agriculture, Abeokuta pp 24-45 